\title{
How to Get from A to B: Fulgens and Lucres, Histrionic Power, and the Invention of the English Comic Duo
}

The first performance of Henry Medwall's Tudor interlude Fulgens and Lucres took place sometime in the 1490s. After some four hundred years of blank silence, the unique copy now at the Huntington Library surfaced in 1919. Consequently one might say (after Pirandello) that the characters reawakened to play their parts again after a rather lengthy hiatus. What's most surprising about this play, however, is that the characters initiate action in a very Pirandellian manner. ${ }^{1}$ I argue that this play originates the English comic duo and that the histrionic process involved is so original that the two principal actors do not even have names. Instead, they freely create themselves from the audience through the play in their moment-to-moment comic action of performance.

From the outset, this sense of performance feels very loose and improvisational as a character designated ' $A$ ' asserts himself from within an audience of banqueters to demand of those banqueters in real-time-and-situation,

A, for Goddis will,

What meane ye, syrs, to stond so still?

Have not ye etyn and your fill

And payd no thinge therfore?

Actually, they have not eaten their fill yet. But they will. That interjection in the form of a loud, long 'A' with which the character A draws attention to the moment abruptly, even rudely, invades the moment in the manner of a loutish 'oi!' today. (In North America such exclamations still sound similar as 'hey!') In doing so this character emerges from the audience to take control of the immediate situation.

Prone to constant error, character A has no name, but he has a hunch that something is going on as he addresses another nameless person in a 
somewhat uncouth but spontaneous inquiry, 'Tell me, what calt, is it not so? / I am sure here shalbe somewhat ado' (1.24-5). A is not sure, but this action in which he finds himself might be a play. He even accuses Character $\mathrm{B}$ - that's his identity in the script - of perhaps being a player. This fellow looks like a player: tall? prepossessed? somewhat extroverted? He dresses like a player: coordinated? colourful? well-coiffed? B denies his status as a player, but $\mathrm{A}$ has a ready explanation in terms of early Tudor self-fashioning that Stephen Greenblatt might have cited:

\section{There is so myche nyce array \\ Amonges these galandis now aday \\ That a man shall not lightly \\ Know a player from a nother man.}

Pirandello couldn't have put it better. Greenblatt actually does footnote A and $\mathrm{B}$, and their fully scripted conversation, but only as related to what he calls the 'essence of sprezzatura to create the impression of a spontaneous improvisation'. ${ }^{3}$ I would agree but argue that much more is at stake and indeed conveyed through the metadramatic complications and power of this play. With plenty of room for unscripted comment and physicality, these two 'waiters' A and B get involved in a rehearsed play called 'Fulgens and Lucres' wherein they constantly confuse, misinterpret, and ultimately convey new forms of Tudor competition and performance.

In The Politics of Performance in Early Renaissance Drama, Greg Walker offers a nuanced discussion of household theatre and the effective counsel involved in such early Tudor entertainment. Quite apart from direct propaganda and forced demonstrations of power, this drama, while certainly sensitive to social status and ceremony, subtly balanced moral assertion and suspension in its awareness of its own license as 'play'. Walker urges that we 'refocus our attention on the element of process at work here and look not primarily at the apparently contradictory elements of confrontational criticism or affirmative compliment to be found in the plays, but at the way these two are combined in a strategy of engaging persuasion.. ${ }^{4}$ For Fulgens and Lucres, such persuasion involves the power of performance itself, a performance that undermines even as it engages an old (and ongoing) story of marriage choice with some surprising, refreshing, even paradoxically informative critical adjustments. 
While clearly a product of humanist education, Fulgens and Lucres wears its learning very lightly, even satirically. It relegates a formal debate for the marriage favour of Lucres, daughter of Roman senator Fulgens, to an inset play performed by recognizably retrograde actors, as opposed to the unpredictably inane - but much more dramatically interesting - actions of A and B. In so doing Fulgens and Lucres contests and conveys cultural meanings related to performance, improvisation, variety, novelty, and absurdist realization of practical impracticalities. Constantly opposed to the cultural input of its own implicit Roman debate, the play unsettles preconceived moral debate forms of pre-Tudor drama to assert instead (even as it co-opts and ludicrously foregrounds classical débat forms) its own cultural significance as English comedy. A noble household drama in 1490s England might be expected to do otherwise. That it refuses to do so - even within the restrictions of an arch-episcopal household - only further emphasizes its significance as a form of exciting, risk-taking theatre. Indeed, as a play dealing fast and loose with a debate about nobility and marriage, Fulgens and Lucres makes a vital and previously unexamined incursion into one of the most significant effects of metadrama. It foregrounds a sense of insecurity through the crossing of boundaries between audience(s) and performer(s) to inform a wider consciousness of class, authority, and autonomy. Through invasions of energetic farce, histrionic self-consciousness, absurdist comic satire, and even a new sense of liberté in performance, the play of Fulgens and Lucres presents the very situations, complications, political possibilities, and sheer fun of performance itself.

Most critics don't like fun. They prefer culture, history, interpretation, moral renovation, hypothetical speculation, or blissful lack of closure. If Fulgens and Lucres cannot be made relevant to some specific historical circumstance - the experiences of young Sir Thomas More in service to Cardinal Morton; the marriage negotiations for the Prince Arthur-Catherine of Aragon match; or the details of the Charles Brandon-Mary Tudor affair - it is hardly worth discussing at all. ${ }^{5}$ Greg Walker alone of recent critics considers the playful self-referentiality of the play but mostly to emphasize the actions of $\mathrm{A}$ and $\mathrm{B}$ as complementary subplot for a more important moral debate on true nobility. Meg Twycross actually staged the play thirty years ago at Lancaster, but even she, in her now classic essay 'The Theatricality of Medieval English Plays', credited actorly possibilities while falling back on special pleading with regard to the 'Fulgens and Lucres' marriage debate, declaring: 'long rhetorical speeches are not by definition "boring"'.6 Actually, they are. 
Their inherent dullness relegates them to the inset plot of this play even though the classical Roman names form the title of the play overall. Significantly, Fulgens and Lucres neither begins nor ends with 'Fulgens and Lucres'. This pre-packaged Roman debate (translated very loosely from an Italian original) actually forms the subplot of Medwall's English play, a play that opens with the boisterous and self-conscious interaction of a pair of waiters identified only as 'A' and 'B' who attract attention and hold attention through to the end of their play. In so doing, they're both waiting and ordering at the table of the great - perhaps the banqueting hall at Lambeth Palace, London home of Medwall's patron John Morton, archbishop of Canterbury and lord chancellor to King Henry viI.

But that was then. In the present tense of performance, A and B initiate and manipulate the interests of the audience because they are audience members too. Character B takes fifty-five lines to explain the 'Fulgens and Lucres' plot involving the predictable marriage contest of Cornelius (aristocratic bad guy and therefore father's choice) and Gayus (self-made good guy and therefore daughter's choice) for the hand of the noble Lucres. At the end of this rather dull explication - wherein Gayus (obviously and irrelevantly) wins betrothal to Lucres - A's question is as witheringly incredulous as it is comical: 'And shall this be the proces of the play?' (1.125).

$\mathrm{A}$ and $\mathrm{B}$ can do much better. They insist that they are not involved in the play, thereby registering their further involvement in the play. They concede that they enjoy watching plays, but they also express gradual awareness that they somehow form the energies of the play in which they find themselves. As moral agents, moreover, they consider themselves as rather loftily, even powerfully, neutral within their self-conscious sense of performance and 'little guy' sense of propriety - all this in opposition to the histrionics of the truly powerful, of whom A observes, 'He must both lye and flater now and than / That castith hym to dwell amonge worldly men' (1.166-7). But B expresses an even more aggressive sense of metatheatre and morality within 'Fulgens and Lucres' by demanding to know, who cares? He directly asks about the audience of which he is a part:

Why shulde they care?

I trow here is no man of the kyn or sede

Of either partie, for why they were bore

In the cytie of Rome as I sayd before. 
All these events happened long ago and far away in Rome, but they are also happening now, in 1490s England, as the inset 'actors' playing Fulgens, Lucres, Gayus, and Flaminius enter to play their parts and A and B fall over each other in an attempt to sort out their positions and situations.

With surprising adroitness, character B offers to step in and assist in the 'Fulgens and Lucres' presentation, but A tells him to stay in the audience and avoid destroying the play. B, however, knows better, as he responds,

Distroy the play quod a? Nay, nay,

The play began never till now!

I wyll be doing, I make God a vow.

B knows that he and A are the play. To A's nonplussed query, 'what'll I do?' B's response is brilliant: they will both play. They will perform as if their lives depended on it, because — in a powerfully self-conscious and metatheatrical way - their lives do indeed depend upon performance in the very moment of its realization.

Way back in 1962, David Bevington clarified the proportions of the play as follows: 'Fulgens and Lucrece is really two plays, a debate on gentleness and nobility and a compilation of humorous skits added in the manner of a popular entertainment.' 7 Later in the twentieth century, Roberta Mullini, while aware of metatheatrical possibilities, opted simply for dramatic literalism: 'The role of A and B in the play appears to be exactly that of helpers of the playwright, an expression of his concern for the incisiveness of his play'. ${ }^{8}$ In effect, however, A and B constantly subvert the playwright through their ungovernable play, and 'incisiveness' does not seem to be their strong suit. Instead, I propose that we put the cart back before the horse - where it belongs for this play - to recognize that A and B constantly focus and deflect attention away from the inset play of 'Fulgens and Lucres' and thus away from the usual expectations of Tudor theatre.

I generally agree with recent critic Aaron Kitch's comments on the play's 'obvious experiments in dramatic form and function in relation to the social and political history of early Tudor England's but intend to argue for the play's even more obvious relation to theatre and performance. Like other critics, Kitch labels the actions of A and B as an 'elaborate framing subplot. ${ }^{10}$ Indeed, it's so elaborate that it forms - I would argue - the main plot of the play. Hereby, Fulgens and Lucres in performance provides not so much a predictable moral contest as it does a newly empowered transitional 
consciousness. Powerfully histrionic, this consciousness represents, even as it mediates between, a humanist English present and a classical Roman past, from now to then and from then to now, from physical (and somewhat ridiculous) present to mannered (and therefore respectable) past, from perception to performance and from performance back to perception again. Given such fluid emphases, any spectator quickly realizes that the play is all about social and political positioning through the assertions of comedy, contest, ridiculous improvisation, and self-conscious play - activities at which $\mathrm{A}$ and $\mathrm{B}$ seem to be experts almost without trying.

Fulgens and Lucres paradoxically subverts its own title where the inset classical performance of 'Fulgens and Lucres' - about which everyone is so anxious - gets constantly subordinated to the wacky improvisations of $\mathrm{A}$ and $\mathrm{B}$ and their preposterous concerns within the context of a new Henrician administration. Look around yourselves, the play seems to say, you are the show, and together as actors we provide the action. Such perception of metadrama asserts a significant effect, foregrounding a sense of insecurity through a crossing of boundaries between audience and performer. But that felt insecurity gets reconfigured through its very performance to demystify and undercut the significance of 'Fulgens and Lucres' while emphasizing the significance of $\mathrm{A}$ and $\mathrm{B}$ and the activities of the Tudor banquet table. Moral significance and political action reside here in performance in $1490 \mathrm{~s}$ England.

Citing plays from a hundred years later such as Shakespeare's Hamlet, Beaumont's Knight of the Burning Pestle, Jonson's Staple of News, and Massinger's The Roman Actor, Bill Angus describes 'serious uncertainties in the Renaissance about the process of interpretation, resulting in an incredulity toward authority that finds its way into metadramatic texts. ${ }^{11}$ In Medwall's Fulgens and Lucres, however, such uncertainties and incredulity form the basis of the play from its beginning — so much so that this early metadramatic play details its plot at the outset. Beyond medieval convention, such foregrounding of the nested play-within is absolutely necessary for a new cultural self-consciousness, one that asserts itself as new and newly empowered within an embryonic meritocracy of performance. Hereby the title Fulgens and Lucres masks the real emphasis of the play on a different duo: the English comic duo - two nameless, masterless men — unemployed, ineffectual, well-meaning, and clever in so many unofficial ways while also at liberty and sensitive to literal possibilities. Together they explode the tricky-hungry-servant comic 
type from Roman comedy, instead placing the emphasis of this play where it belongs, in the now of comic performance.

Consequently, A and B never presume to compete for timeless moral truth. Instead, they compete actively for immediate and momentary dramatic truth. Medievalist literary critic James Simpson allows that A and B, in their own words, 'stir folk to mirth and game' and goes on to describe the sort of paradoxical effect that I am arguing for: "The "mirth" they introduce is, however, so insistent and so directly pertinent to the main plot that what is ostensibly the sub-plot cannot help but modify the simplicities of the main plot, even as it would dismiss itself as irrelevant mirth. ${ }^{12}$ As a feature of metadrama from the beginning, A and B step across a barrier of real service as waiters to perform fictional service as actors. They hereby promote themselves histrionically above a previous station of service to a new position of performance. As Simpson affirms, 'Already, then, the play presents promotion across apparently insuperable barriers, but in so doing it qualifies any simple version of nobility of soul'. 13 The two actors are precisely not noble, but they will compete for the affections of Lucres's maid Joan in a parallel debate along physical lines of dance, tumbling, sex, song, and comedy with much in the way of ribald action and commentary. A readily concedes of himself and $\mathrm{B}$ that

This felowe and I be maysterles

And lyve moste parte in ydelnes,

Therefore some maner of besenes

Wolde become us both well.

They feel modern, in-the-moment, and improvisational with their wisecracks, wrestling, and somewhat abashedly self-conscious perceptions. They indeed in-form the show. The upper class Roman characters perform in a lesser key of past-tense fiction and struggle never to break character nor to interact with the audience.

Not so A and B. They accord significance to the Roman plot by their association with us as audience. The two plots cross over as A overhears Cornelius's wooing of Lucres and makes application to serve him. But everyone knows that you cannot trust an actor, a player - someone who represents himself as someone else. Of course Cornelius, oblivious to play, asks A for personal references. A therefore elicits B for help, but only after some improvisational audience interaction, observing 'Here is a gentilman that wolde 
truste me' (1.626). A has the power momentarily to single out an audience member, to abash or otherwise have fun with this figure - who may well hold significant personal power - with the saucy observation: 'By my faith, go where he shall, / It is as honest a man as ony in the reall' (629-30). The open-ended sarcasm of the line applies to the entire banquet table of Tudor nobles and politicos, but A rescues it immediately by returning to the play and emphatically recognizing B's entry: 'By God here is one best of all!' (633). Of course B is only 'best' within the terms of the play, and A registers equivocal trust in him through the ironic observation 'I never coude by hym any thing espie / But that he was as true a man as I' (642-3). Together, A and B are true to performance and therefore true to each other's histrionic power of performance. They are in control of this room through the power of play. This power B credits just as ironically in his assurance that anyone, in the play or in the audience, can certainly trust A 'hardely' (650). Throughout, metadramatic irony trumps even as it informs audience credibility.

Ruth Lexton relates the historical resonances of Fulgens and Lucres to the situation of nobility and protocol under Henry vir, but she considers metadramatic possibilities only to dismiss them: 'Are A and B the rogue elements in the debate on nobility, their compelling sub-plot a subversion of the noble debate? If the sub-plot is subversive, and $\mathrm{A}$ and $\mathrm{B}$ are vicious, then Fulgens begins to look like a case of Vice undermining Virtue. ${ }^{14}$ Of course Vice often undermines Virtue in the drama of this period, adding contextual spice and action to flesh out the letter of instruction with the spirit of play. Almost oblivious to ironic possibility, Lexton concedes that 'Medwall draws attention to the fact that low-status knaves can consider a noble matter'. ${ }^{15}$ In fact and practice they do much more, purposefully overstepping their bounds and effectively taking the inset play to new realms of fun and frolic that are shared, experienced, and appreciated by the audience and to which the nobles within the play — and audience — might be impervious.

At the centre of the play, A and B interact in a loose variety of performance registers with 'Ancilla', Lucres's maid, known familiarly to them both as 'Jone' $(1.1083,1120)$, who crosses over into their performance space with surprising alacrity. She gets introduced in song as B sings of his desire for a sexy English girl:

It is a lytyll praty moucet,

And her voice is as doucett

And as swete as resty porke. 
Her face is some what browne and yellow,

But for all that she hath no fellow

In syngynge hens to Yorke.

(Of course she is actually a fellow — but one with a great singing voice.) As soon as he sees her, he grabs her with little in the way of romantic formality, 'Cockis body, here she is!' (859), motivating her perhaps equally familiar response, 'Tusshe, I pray you, let me go! / I have somewhat els to do' (862-3). But her ostensible mission on behalf of her mistress Lucres gets subordinated immediately to her repartee with $\mathrm{B}$. He makes direct demands and even puckers up for a juicy kiss, motivating Jone's dry reaction: 'The devyllis torde! / The man is madde I trowe!' (998-9). But she does concede a single kiss that is witnessed by $\mathrm{A}$, who reenters at precisely this point with a suggestion that B 'Set even suche a patche on my breche!' (1006). As we will see, ass-kissing gains more and more significance in this play.

This fast-paced, immediate, three-cornered comical interaction of A, B, and Jone parallels and interpenetrates the slow-paced, delayed, high-minded debate contest of Cornelius, Gayus, and Lucres. Always physical, A and B begin a wrestling contest that morphs into B's showy and dramatic action of officially throwing down his glove and challenging A to a joust. Taking up the challenge immediately, A is yet a bit uncertain, wondering, 'Where shall I have a hors?' (1.1167) only to be reassured by B in the following remarkable couplet: 'Nay, we shall nede no horse ne mule, / But let us j[o]ust at farte prycke in cule' (1168-9). Some joust! Whereas insults and wrestling might qualify as informal competition, this mock-jousting interaction reaches into absurdity in terms of conception and performance.

Both A and B are trussed up in squatting positions with some sort of 'prycke', i.e. a prodding or poking instrument — the text mentions a 'spere' and 'staff' $(1.1186,1187)$ specifically. With this prycke they attempt to strike each other in the ass while hopping clumsily on their haunches. Their action clearly parodies aristocratic forms of jousting and combat as they arm and face each other for the dubious honour of Jone, 'ye flowre of the frying pane' (1174). And yet this ludicrous mock-joust might be more legitimate than it seems at first thought. In a brilliantly empirical essay, Peter Meredith and Meg Twycross provide photographs of the Lancaster production and report on the complexities of the physical effects it produced. ${ }^{16}$ This mock-athletic action in Fulgens and Lucres holds attention through its ludicrous contrivance and burly unpredictability. Of her production Twycross states, 'Each night it 
was a gamble as to which of the two was going to win the joust!'17 The ironic 'reward' for contestants A and B involves Jone beating and abandoning them both, leaving Gayus from the Roman plot to discover and untie them while marvelling at their far-fetched excuses. This fast-paced action of $A, B$, and Jone, followed immediately by Gayus's entrance, feels 'modern' and in-themoment, like their other various wisecracks, songs, and horsings-around, all pitched at attracting, holding, and delighting the attention of an audience and providing it with surprise.

Surprisingly (or not) everything must stop for dinner. A and B simply and abruptly announce that it is time to stop playing and eat. According to A, the play could probably end at this point, too, but B condescends to inform him that Lucres has not yet made her marriage choice. Besides, unlike A and B who are always in character, Gayus and Cornelius require time to ready their arguments and rehearse their lines. B then crosses a further line of consciousness as he orders up the actual meal. Although unrecorded, the meal is real and occurs in real time as part of the play, somewhat like the intermission shenanigans of Pirandello's Tonight We Improvise, wherein the actors appear in the lobby and urge the audience to go home. ${ }^{18}$ In Fulgens and Lucres, A and $\mathrm{B}$ urge the audience to eat, drink, and enjoy their absence!

The performance of re-interrupting the audience at dinner signals the beginning of the second part of the play. At his entrance, A feels moved to recap the plot so that diners in various states of intoxication and drowsiness might get back up to speed on the nature of the action at hand. Likewise the 'actors' need to get back up to performance speed, as A muses idly about where the players are:

I mervell gretely in my mynde

That thay tary so long behynde

Theyre howre for to breke.

The play reaffirms its emphasis on metatheatrical audience involvement by having A muse, 'Let me se, what is now a-cloke', thus cuing offstage knocking that facilitates full reintegration of $\mathrm{A}, \mathrm{B}$, and audience. A reacts to the knock on the door by urging someone in the audience - doubtless someone who would not usually take such an order — to answer it: 'One of you go loke who it is' (74). The door opens and B enters, complaining about the play as if he never left, and characteristically rebutting A's criticism actor-to-actor: 
I am com hedyr att this season

Only at thy byddynge,

And now thou makyst to me a quarrel

As though all the matter were in parell

By my longe taryynge.

Consequently $\mathrm{A}$, in the manner of a Pirandellian stage-manager, must talk $\mathrm{B}$ back into the performance of the play in relation to Lucres and her choice of marriage partner.

If the first half of the play emphasizes athletic contest, the second half is all about performance screw-ups and misinterpretation. Try as he might (and after dinner he thinks it's easy) character B simply cannot successfully get a message from Cornelius to Lucres. Unconscious of his double entendres, Cornelius entrusts $B$ to remind Lucres of a special moment between them when he attempted to fright a bird by casting her musk ball at it:

I kyst it as straight as ony pole,

So that it lyghtyde evyn in the hole

Of the holowe ashe.

$B$ repeats the message, accenting the double entendres for audience pleasure and consoling himself that he is merely the messenger. His scurrilously incompetent message to Lucres relays the following from Cornelius: 'And than as he sayd, ye dyd no wors / But evyn fayr kyst hym on the noke of the ars' (282-3). At Lucres's shocked denial, B revises in the name of anatomical accuracy,

Trouth, it was on the hole of thars I shulde say -

I wyst well it was one of the too,

The noke or the hole.

Again Lucres reacts with open-mouthed shock. With mounting impatience, B tries again to certify his message: 'By my faith, ye kyst hym or he kyst you / On the hole of thars, chose you now' (2.288-9). To B, that's certainly a lot of ass-kissing. Luckily, Lucres is able to rescue the situation and pacify $\mathrm{B}$ by explaining his mistake to him: 
I know what thyn erande is,

Though thow be neclygent,

Of thy foly thou mayst well abasshe,

For thou shuldis have sayde the hollow asshe:

That hole thy mayster ment.

Ash, ass - it's all too much for B. In obvious relief, he takes his exit to conclude a laugh-filled beat of comedy.

Then it's A's turn to display his incompetence. Full of hang-dog humility, he tries to convey a message to Lucres from his master - if he could only remember his master's name. Lucres tries vainly to prompt him, even to the point of inquiring after A's own name. But A can't even remember that! The stage direction mandates that $A$ then scratch his head and pause to reflect before answering in the manner of an actor forgetting his lines:

By this lyght, I have forgotten!

How be it, by that tyme I have spoken

With som of my company,

I shall be acerteyned of this gere.

But the only form of consultation is performance. In the moment that he is conscious of his unascertainable role, he actually plays his role. Forget about strict and endlessly duplicated responses. He is a player and anything can happen within the gaps of play.

Ostensibly, Fulgens and Lucres affirms that 'gentilmen of name' should 'eschew / The wey of vyce and favour vertue' (2.894-5). So says B in a speech with which he attempts to conclude the play. But neither A nor B are 'gentilmen' nor do they have names. '[V]ertue' in this play is only virtue as understood by $\mathrm{A}$ and $\mathrm{B}$, and their understanding of this concept is radically uncertain. In an attempt to summarize the marriage plot, B blusters emphatically with regard to Lucres, 'By my faith, she saide - I tell the true -l That she wolde nedis have hym for his vertue' (839-40). But A responds nonplussed: 'Vertue? What the devyll is that?' (842). In reply, B confirms that he has no idea what it means but that is what Lucres said and everyone in the audience heard it. Of course $\mathrm{A}$ and $\mathrm{B}$ are also arguing with the audience at this point about virtue, gendered action, authorial intention, and even whether or not the play is actually over. Neither one of them is certain about anything outside of their performance. A even asks his partner directly, 'Why than, is the 
play all do?' (875). The answer is 'No': the play will conclude only when A and B stop talking. B gets even more metadramatic in the final lines as he attempts to claim direct authority from the author in challenging anyone in attendance to write a better conclusion and declaring that the author himself

wyllyd me for to say.

And that done, of all this play

Shortely here we make an end.

That is the last line. Significantly, the play ends when B says 'end', followed perhaps by further stage business, a full cast dance, or otherwise awkwardly kinetic departure such as the Marx Brothers would make famous on film in the twentieth century.

$A$ and $B$ are a pair of self-conscious boobs but very intelligent self-conscious boobs - like Vladimir and Estragon in Waiting for Godot or Laurel and Hardy in countless short films. They condition us not to take anything very seriously. They do indeed parody the stiff formality of ancient Rome and the old story of Fulgens and Lucres, but they do so by metatheatrical default as they instigate the real action of the play and find their way into the classical marriage debate through loop-holes of performance. They do so, moreover, without the spite, trickery, or comic immorality of earlier Vice-like figures. In a sense the medieval Vice has split and become two unemployed guys with confused but best intentions, unable to accomplish anything significant except themselves. They self-invent through their back-and-forth performance.

The overwhelming irony of the play involves A and B as masterless men who are also masters of the action wherein they adopt new masters as incompetent as themselves. They discover herein a new freedom and mobility. More deeply, they parody their own pastime as actors within a zone of performance in which they must play or perish. Consequently Fulgens and Lucres does not really assert a moral lesson. Nor is it an analogue of humanist pedagogy related to government. The 'real' message of the play (pace humanist critics) does not relate to Lucres's choice of true nobility in marriage. Rather (pace Marshall McLuhan) the message is in the medium of humanist performance itself. And that meaning is not fastened to a dead past. Rather, it exercises itself in a fully meaningful, innovative, and self-conscious present that insists upon performance as the creation of identity itself: from A to B, from $\mathrm{B}$ to $\mathrm{A}$, and in performance back to the audience again. 


\section{Notes}

An earlier version of this article was presented at the Early Modern Studies Conference 'Controversy, Protest, Ridicule, Laughter, 1500-1750' at the University of Reading, July 2010. My thanks go especially to Agnes Matuska, Mark Hutchings, and Stephen Longstaffe for their insightful comments. My thanks go as well to the helpful anonymous readers at Early Theatre.

1 Italian playwright Luigi Pirandello (1867-1936) is probably best known for his 1921 play Six Characters In Search Of An Author but wrote a number of other plays such as Right You Are (If You Think You Are) (1917) and Tonight We Improvise (1930) that deliberately blur the line between onstage and offstage reality.

2 Throughout this article I quote from and cite the Fulgens and Lucres text established by Alan Nelson in The Plays of Henry Medwall (Cambridge, 1980).

3 Stephen Greenblatt, Renaissance Self-Fashioning: From More to Shakespeare (Chicago, 1980), $297 \mathrm{n} 7$.

4 Greg Walker, The Politics of Performance in Early Renaissance Drama (Cambridge, 1998), 74.

5 For these historical readings, see respectively Greg Walker, 'Fulgens and Lucres and Early Tudor Drama', Garrett A. Sullivan, Jr, Patrick Cheney, and Andrew Hadfield (eds), Early Modern English Drama: A Critical Companion (Oxford, 2006), 23-34; Roberta Mullini, 'Fulgens and Lucres: A Mirror Held Up to Stage and Society', European Medieval Drama 1 (1997), 203-18; and R.A. Godfrey, 'Nervous Laughter in Henry Medwall's Fulgens and Lucres', Tudor Theatre 3 (1996), 81-96.

6 Meg Twycross, 'The Theatricality of Medieval English Plays', Richard Beadle and Alan J. Fletcher (eds), The Cambridge Companion to Medieval English Theatre, 2nd ed. (Cambridge, 2008), 26.

7 David Bevington, From Mankind to Marlowe: Growth of Structure in the Popular Drama of Tudor England (Cambridge MA, 1962), 44.

8 Mullini, 'Fulgens and Lucres: A Mirror', 211.

9 Aaron Kitch, 'Medwall's "Condycion": Fulgens and Lucrece and the New Tudor Drama', Cahiers Elisabethains 68 (2005), 1.

10 Ibid.

11 Bill Angus, 'Metadrama, Authority, and the Roots of Incredulity', Daniel K. Jernigan (ed.), Drama and the Postmodern: Assessing the Limits of Metatheatre (Columbia, 2008), 45.

12 James Simpson, The Oxford English Literary History Volume 2: 1350-1547 Reform and Cultural Revolution (Oxford, 2002), 550. 
13 Ibid.

14 Ruth Lexton, 'Henry Medwall's Fulgens and Lucres and the Question of Nobility Under Henry vir', Linda Clark (ed.), The Fifteenth Century viII: Rule, Redemption and Representations in Late Medieval England and France (Woodbridge, 2008), 178.

15 Ibid.

16 Peter Meredith and Meg Twycross, "Fart Prycke in Cule” and Cock-Fighting', Medieval English Theatre 6 (1984), 30-9.

17 Ibid, 37.

18 For an accessible English translation see Luigi Pirandello, Tonight We Improvise, trans. Samuel Putnam (New York, 1932). 